\title{
Incidence of Ureaplasma urealyticum in endourethral swabs compared with first voided urine from men
}

\author{
I H AHMED-JUSHUF, * B C PRATT, $\dagger$ O P ARYA* \\ From the departments of ${ }^{*}$ Genitourinary Medicine and $\dagger$ Medical Microbiology, University of Liverpool
}

SUMMARY The incidence of Ureaplasma urealyticum in endourethral swabs was compared with that in first voided urine specimens from 171 male patients. The organism was isolated from the urethras of $72(42 \%)$ and from the urine of $66(39 \%)$. The interval since last voiding urine did not significantly influence the incidence of infection or ureaplasma counts in either type of specimen. Urethritis was strongly associated with ureaplasma counts of $\geqslant 5 \times 10^{5}$ colour changing units $(\mathrm{ccu}) / \mathrm{ml}$ in the urethra and $\geqslant 5 \times 10^{3} \mathrm{ccu} / \mathrm{ml}$ in urine.

Ureaplasma urealyticum was first isolated from the urethra of a man with non-gonococcal urethritis (NGU) in 1954.' Since then, several studies have shown evidence of an aetiological role of $U$ urealyticum in NGU in men. ${ }^{2-5}$ The criteria for a micro-organism to be regarded as a cause of NGU have been considered by Taylor-Robinson, who concluded that these criteria have for the most part been met in the case of $U$ urealyticum. ${ }^{6}$

The isolation of $U$ urealyticum from male urethras entails culture of material obtained from endourethral swabs-a procedure that is mandatory for isolating Neisseria gonorrhoeae and Chlamydia trachomatis. To minimise patient discomfort, the number of endourethral swabs taken should be limited. A possible alternative to endourethral swabbing is to try to culture the organism from a specimen of first voided urine. Several studies have shown higher incidences of mycoplasmas (which include ureaplasmas) from urethral than from urine cultures. ${ }^{578}$ None of those studies, however, investigated the effects of the interval since last voiding urine on the numbers of men infected or on the mycoplasma counts, or both.

The investigation published here was therefore undertaken to compare not only the incidence of infection and mycoplasma counts in endourethral swabs and first voided urine, but also to assess how the interval since last voiding urine influenced these findings.

Address for reprints: Dr I H Ahmed-Jushuf, Department of Genitourinary Medicine, Royal Liverpool Hospital, Prescot Street, Liverpool L7 8XP

Accepted for publication 11 June 1987

\section{Patients and methods}

New male patients attending the genitourinary medicine clinic at the Royal Liverpool Hospital were enrolled in the study, provided that they had not received antibiotics in the previous four weeks. Their symptoms and signs, demographic data, and history of sexually transmitted diseases and recent exposure were recorded. We used plastic loops to collect urethral specimens for smears for Gram staining and for inoculation direct on to modified Thayer-Martin medium for culturing $N$ gonorrhoeae. Urethritis was diagnosed when 5 or more polymorphonuclear leucocytes were observed in at least five high power fields ( $\times 1000$ magnification).

We obtained specimens for culturing $U$ urealyticum using sterile cotton tipped ENT swabs (Medical Wire and Equipment) inserted 3-5 cm into the urethra and rotated several times. The swabs were transferred immediately to $2 \mathrm{ml} \mathrm{A3XB}$ transport medium (Difco tryptic soy broth containing sterile L-cysteine hydrochloride $0.01 \% \mathrm{w} / \mathrm{v}$ and bovine albumin $1 \% \mathrm{w} / \mathrm{v}$, final pH 6.0). ${ }^{9}$ Specimens $(20 \mathrm{ml})$ of first voided urine were also collected, and the interval since last voiding was noted. In the laboratory, the urethral specimens were thoroughly agitated to dislodge the organisms, and the swabs were discarded. The urine samples were centrifuged at $1500 \times g$ for 10 minutes in an MSE Centaur 1 centrifuge, and any pellet was resuspended in $2 \mathrm{ml}$ supernatant.

The swab specimens and the concentrated urine were titrated using serial tenfold dilutions in $1.8 \mathrm{ml}$ volumes of broth that contained urea (Difco PPLO broth base containing sterile fresh yeast extract $10 \% \mathrm{v} /$ 
Table 1 Isolation of Ureaplasma urealyticum from 171 men in relation to interval since last voiding urine

\begin{tabular}{lrll}
\hline \multirow{2}{*}{$\begin{array}{l}\text { Interval } \\
\text { (hours) }\end{array}$} & No & \multicolumn{2}{l}{ No $(\%)$ yielding U urealyticum from: } \\
\cline { 3 - 4 } & 9 & $3(33)$ & Urine $(n=66)$ \\
\hline$<1$ & $n=72)$ & $3(33)$ \\
$1-2$ & 46 & $25(54)$ & $22(48)$ \\
$2-3$ & 47 & $18(38)$ & $17(36)$ \\
$3-4$ & 39 & $15(39)$ & $13(33)$ \\
$>4$ & 30 & $11(37)$ & $11(37)$ \\
\hline
\end{tabular}

$\mathrm{v}$, unheated horse serum $20 \% \mathrm{v} / \mathrm{v}$, urea $0 \cdot 1 \% \mathrm{w} / \mathrm{v}$ phenol red $0.002 \% \mathrm{w} / \mathrm{v}$, and ampicillin $500 \mu \mathrm{g} / \mathrm{ml}$, final $\mathrm{pH} 6.0$ ) and incubated at $37^{\circ} \mathrm{C}$. The titres of $U$ urealyticum were expressed as colour changing units (ccu)/ml. No colour changes were seen after incubation for $\mathbf{4 8}$ hours. Specimens were processed as soon as possible after collection; if delay was unavoidable, they were stored at $4^{\circ} \mathrm{C}$.

\section{Results}

We obtained specimens from a total of 171 patients enrolled in the study. Bacterial growth was observed in only six of these specimens. $U$ urealyticum was isolated from the urethras of $72(42 \%)$ and from the urine of 66 (39\%) patients, not a significant difference. Table 1 shows the numbers of men yielding $U$ urealyticum from their urethras or urine in relation to the interval since urine was last voided. The differences between yields from the two sources were small and not significant.

Table 2 shows that ureaplasma counts of $\geqslant 5 \times 10^{5}$ $\mathrm{ccu} / \mathrm{ml}$ were found in $35 \%(25 / 72)$ of patients yielding cultures from their urethras compared with $17 \%$ (11) 66) of those yielding cultures from urine. This difference was significant $\left(\chi^{2} 4.92 ; p<0.05\right)$. Of the 25 patients with urethral ureaplasma counts of $\geqslant 5 \times 10^{5}$ $\mathrm{ccu} / \mathrm{ml}, 23 \mathrm{had}$ urine counts of $\geqslant 5 \times 10^{3} \mathrm{ccu} / \mathrm{ml}$. Furthermore, all 18 patients who had urethritis and urethral ureaplasma counts of $\geqslant 5 \times 10^{5} \mathrm{ccu} / \mathrm{ml} \mathrm{had}$ counts of $\geqslant 5 \times 10^{3} \mathrm{ccu} / \mathrm{ml}$ in their urine (table 3 ).

Table 2 Ureaplasma counts related to interval since last voiding urine

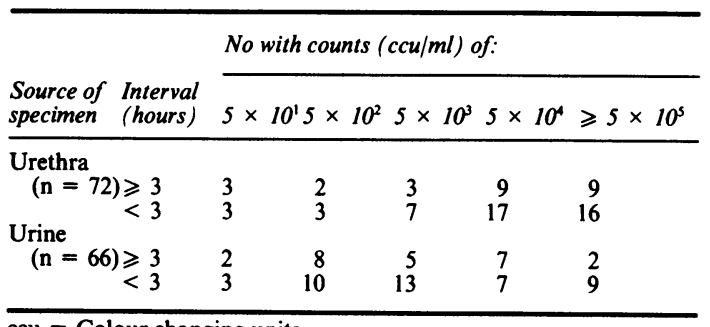

Table 3 Association of ureaplasma counts with urethritis

\begin{tabular}{|c|c|c|c|}
\hline $\begin{array}{l}\text { Source of } \\
\text { specimen }\end{array}$ & $\begin{array}{l}\text { Ureaplasma } \\
\text { counts }(\mathrm{ccu} / \mathrm{ml})\end{array}$ & $\begin{array}{l}\text { No(\%) } \\
\text { with } \\
\text { urethritis }\end{array}$ & $\begin{array}{l}\text { No(\%) } \\
\text { without } \\
\text { urethritis }\end{array}$ \\
\hline \multirow[t]{2}{*}{$\begin{array}{l}\text { Urethra } \\
\quad(\mathrm{n}=72)\end{array}$} & $\begin{array}{l}\geqslant 5 \times 10^{5} \\
<5 \times 10^{5}\end{array}$ & $\begin{array}{l}18(51) \\
17(49)\end{array}$ & $\begin{array}{r}7(19) \\
30(81)\end{array}$ \\
\hline & & \multicolumn{2}{|c|}{$\chi^{2} 7.01 ; p<0.01$} \\
\hline \multirow[t]{2}{*}{$\begin{array}{l}\text { Urine } \\
\qquad(n=66)\end{array}$} & $\begin{array}{l}\geqslant 5 \times 10^{5} \\
<5 \times 10^{5}\end{array}$ & $\begin{array}{l}10(31) \\
22(69)\end{array}$ & $\begin{array}{c}1(3) \\
33(97)\end{array}$ \\
\hline & & \multicolumn{2}{|c|}{$\chi^{2} 7.58 ; p<0.01$} \\
\hline \multirow[t]{2}{*}{$\begin{array}{l}\text { Urine } \\
\qquad(n=66)\end{array}$} & $\begin{array}{l}\geqslant 5 \times 10^{3} \\
<5 \times 10^{3}\end{array}$ & $\begin{array}{r}28(88) \\
4(13)\end{array}$ & $\begin{array}{l}15(44) \\
19(56)\end{array}$ \\
\hline & & \multicolumn{2}{|c|}{$\chi^{2} 11.8 ; p<0.001$} \\
\hline
\end{tabular}

ccu $=$ Colour changing units.

Table 2 also shows the ureaplasma counts in urethras and urine related to intervals since last voiding urine. As with overall isolation rate, the time since last voiding urine did not significantly influence the numbers of organisms isolated from the two types of specimen.

A significant association was, however, found between the presence of urethritis and ureaplasma counts of $\geqslant 5 \times 10^{5} \mathrm{ccu} / \mathrm{ml}$ from both urethral swabs and urine (table 3). Furthermore, 88\% (28/32) of patients with urethritis had ureaplasma counts of $\geqslant 5$ $\times 10^{3} \mathrm{ccu} / \mathrm{ml}$ in the urine compared with $44 \%(15 / 34)$ in whom urethritis was not detected. This difference was significant $\left(\chi^{2} 11 \cdot 8 ; \mathrm{p}<0.001\right)$.

\section{PATIENTS YIELDING CULTURES FROM THE URETHRA ONLY}

Of six patients who yielded cultures from the urethra only, three, all with ureaplasma counts of $5 \times 10^{1} \mathrm{ccu} /$ $\mathrm{ml}$, had NGU. The three who were found not to have urethritis on that occasion had ureaplasma counts of 5 $\times 10^{3} \mathrm{ccu} / \mathrm{ml}, 5 \times 10^{4} \mathrm{ccu} / \mathrm{ml}$, and $5 \times 10^{5} \mathrm{ccu} / \mathrm{ml}$. The interval since these men had last voided urine ranged between one and four hours. The failure to cultivate ureaplasmas from the urine of these patients was not related to the presence of urethritis or to the interval since they last voided urine.

\section{Discussion}

We have shown no significant difference between the incidence of isolating $U$ urealyticum from endourethral swabs and first voided urine. Furthermore, the interval since last voiding urine did not significantly influence the incidence or the ureaplasma counts from either the urethra or urine. Ureaplasma counts from urethral swabs were, however, significantly higher than those from first voided urine, which confirms the findings of other workers. ${ }^{78}$ 
A strong association was shown between the presence of urethritis and ureaplasma counts of $\geqslant 5 \times$ $10^{5} \mathrm{ccu} / \mathrm{ml}$ from the urethra. Whereas $U$ urealyticum can be isolated in large numbers $\left(\geqslant 5 \times 10^{5} \mathrm{ccu} / \mathrm{ml}\right)$ from men without urethritis (7/37) in our study), the organism is isolated more often from men with NGU. ${ }^{10}$ Our results further show a strong association between the presence of urethritis and ureaplasma counts of $\geqslant 5 \times 10^{3} \mathrm{ccu} / \mathrm{ml}$ in urine culture. No such correlation could be shown with counts of $<5 \times 10^{5}$ $\mathrm{ccu} / \mathrm{ml}$ from urethral or $<5 \times 10^{3} \mathrm{ccu} / \mathrm{ml}$ from urine cultures. This suggests that a count of $\geqslant 5 \times 10^{3} \mathrm{ccu} /$ $\mathrm{ml}$ in urine cultures may be equated with a urethral count of $\geqslant 5 \times 10^{5} \mathrm{ccu} / \mathrm{ml}$.

We conclude that first voided urine can provide a reliable alternative to endourethral swabbing to isolate $U$ urealyticum, and that the incidence of isolating the organism is not significantly influenced by the time since last voiding urine.

\section{References}

1 Shepard MC. Recovery of pleuropneumonia-like organisms from negro men with and without non-gonococcal urethritis.
American Journal of Syphilis, Gonorrhea and Venereal Diseases 1954;38:113-24.

2 Wong JL, Hines PA, Brasher MD, Rogers GT, Smith RF, Schachter $J$. The etiology of non-gonococcal urethritis in men attending a venereal disease clinic. Sex Transm Dis 1977;4:4-8.

3 Prentice MJ, Taylor-Robinson D, Csonka GW. Non-specific urethritis: a placebo controlled trial of minocycline in conjunction with laboratory investigations. British Journal of Venereal Diseases 1976;52:269-75.

4 Taylor-Robinson D, Csonka GW, Prentice MJ. Human intraurethral innoculation of ureaplasmas. $Q \mathrm{~J}$ Med 1977;46:309-26.

5 Bowie WR, Wang SP, Alexander ER, et al. Etiology of nongonococcal urethritis. Evidence for Chlamydia trachomatis and Ureaplasma urealyticum. J Clin Invest 1977;59:735-42.

6 Taylor-Robinson D. Mycoplasma infections of the human urogenital tract with particular reference to non-gonococcal urethritis. Ann Microbiol (Paris) 1984;135A:129-34.

7 Tarr PI, Lee YH, Alpert S, Schumacher JR, Zinner SH, McCormick WM. Comparison of methods for the isolation of genital mycoplasmas from men. J Infect Dis 1976;133:419-23.

8 Mårdh P-A, Weström L. T-mycoplasmas in the genito-urinary tract of the female. Acta Pathol Microbiol Scand (B) 1970;78:367-74.

9 Shepard MC, Lunceford CD. Differential agar medium (A7) for identification of Ureaplasma urealyticum (human T mycoplasmas) in primary cultures of clinical material. J Clin Microbiol 1976;3:613-25.

10 Hunter JM, Smith IW, Puetherer JF, MacAulay A, Tuach S, Young H. Chlamydia trachomatis and Ureaplasma urealyticum in men attending a sexually transmitted diseases clinic. British Journal of Venereal Diseases 1981;57:130-3. 